Hidradenitis suppurativa and pilonidal sinus wounds Hidradenitis, an infection of apocrine sweat glands, affects armpits and groins; pilonidal sinus, a tissue infection caused by ingrowing hair, mainly affects the natal cleft.

Failed, repeated drainage of the abscesses requires complete excision. The defect usually heals by secondary intention. Initially, excision wounds are usually dressed with polymeric foam. Once the wound has reduced in size, a topical antimicrobial dressing (such as those that contain iodine or silver) may be used. However, grafts or flaps are also used, either as the primary treatment or for non-healing wounds. These wounds often become infected and require prolonged treatment to cover Gram positive and anaerobic organisms.

The picture of Ambroise Paré is published with permission from TopFoto. David J Leaper is visiting professor of surgery at the Wound Healing Research Unit, Cardiff University, Cardiff.

The ABC of wound healing is edited by Joseph E Grey (joseph.grey@cardiffandvale.wales.nhs.uk),consultant physician, University Hospital of Wales, Cardiff and Vale NHS Trust, Cardiff, and honorary consultant in wound healing at the Wound Healing Research Unit, Cardiff University, and by Keith G Harding, director of the Wound Healing Research Unit, Cardiff University, and professor of rehabilitation medicine (wound healing) at Cardiff and Vale NHS Trust. The series will be published as a book in summer 2006. Competing interests: DJL has received an educational grant for his research group from Merck Sharp and Dohme and had expenses and a fee paid by Ethicon for attending an advisory panel and for the making of an educational film. For series editors' competing interests, see the first article in this series.

BMJ 2006;332:532-5

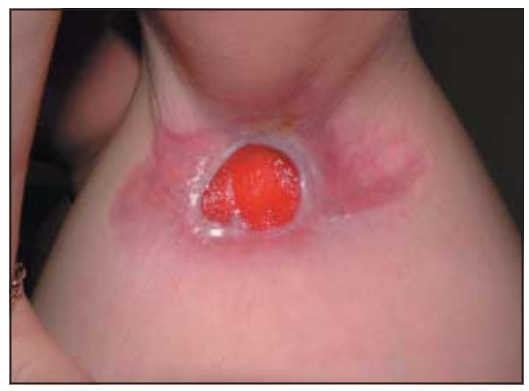

Excision wound in hidradenitis suppurativa

\section{Further reading}

- Téot L, Banwell PE, Ziegler UE, eds. Surgery in wounds. Berlin: Springer, 2004.

- Leaper DJ, Harding KG, eds. Wounds. Biology and management. Oxford: Oxford Medical Publications, 1998.

- Bales S, Harding K, Leaper DJ. An introduction to wounds. London: Emap Healthcare, 2000.

- Leaper DJ, Harding KG, Phillips CJ. Management of wounds. In: Johnson C, Taylor I, eds. Recent advances in surgery. 25th ed. London: Royal Society of Medicine, 2002.

- Leaper DJ, Low L. Surgical access: incisions and the management of wounds. In: Kirk RM, Ribbons WJ, eds. Clinical surgery in general. 4th ed. Edinburgh: Churchill Livingstone, 2004.

- Leaper DJ. Basic surgical skills and anastomoses. In: Russell RCG, Williams NS, Bulstrode CJK, eds. Bailey and Love's short practice of surgery. 24th ed. London: Arnold, 2004.

\title{
When I use a word
}

\section{The very last word}

What is the last word in the dictionary? Easy to answer, you might think. But there is a problem. We talk blithely about "the dictionary," as if there was only one. But there are many, even among monolingual dictionaries of English. And they don't all end with the same headword.

Samuel Johnson's dictionary (1755) ends with zootomy, "dissection of the bodies of beasts." Not a great effort, but then he wasn't going for broke. Collins English Dictionary (sixth edition) makes a better stab: Zyrian, the language spoken by the people of the Komi, in the erstwhile Soviet Union. Zyrian belongs to that curious group of languages, the Finno-Ugric (one of two branches of Uralic, the other being Samoyed). Its main members, despite the geographical divide, are Finnish and Hungarian; it also includes Estonian, Vogul (or Khanti), Ostyak (or Mansi), and the language of Sibelius's Karelia.

The Chambers Dictionary (new ninth edition, 2003) does better still: zythum, a kind of barley beer brewed by the ancient Egyptians and others, from the Greek word zuthos (beer). And a zythepsary is a brewery, got by adding hepsein (to boil). Hepsein also meant to smelt metals and to digest food, reminiscent of another Greek word, pepsis, meaning digestion or fermentation. And the yeast in zythum was called zyme, which gives us enzyme, a word that the Heidelberg physiologist Wilhelm Kühne introduced in 1877 to describe substances such as pepsin.

The Oxford English Dictionary (second edition) takes us further still: zyxt, which turns out to be, wait for it, an obsolete Kentish form of the second person singular present indicative of see. In other words, zyxt is "seest [thou]."

Now the OED is pretty comprehensive, but Philip Gove's controversial Webster's Third New International Dictionary (1961) went one better: zyzzogeton, a genus of large American leaf-hoppers having the pronotum tuberculate and the front tibiae grooved (well that's what the dictionary says).

No dictionary that I've seen has another candidate: zyzzya, from Zyzzya fuliginosa, a marine sponge found in the South Seas. It contains pyrroloiminoquinone alkaloids belonging to the makaluvamine family, which inhibit the enzyme topoisomerase II and so produce a cytotoxic action by cleavage of DNA. And zyzzyposide (modelled on etoposide) would be a great name for an anticancer drug.

However, this is trumped by The American Heritage Dictionary of the English Language (fourth edition, 2000), which has unearthed zyzzyva, any of various tropical American weevils of the genus Zyzzyva, and by The Random House Unabridged Dictionary (1997) with Z-zero particle, one of three particles, intermediate vector bosons, that are thought to transmit the weak nuclear force.

Finally, turn to Mrs Byrne's Dictionary of Unusual, Obscure and Preposterous Words (yes really) of 1974. Mrs Byrne, a concert pianist and composer, was Jascha Heifetz's daughter, Josefa, so it is not perhaps surprising that the last word in her dictionary is musical: zzxjoanw, pronounced ziks-jo'-un and defined as a Maori drum. But anyone with the least smattering of Maori would look suspiciously at those zeds, the ex, and the jay. Here's a sample of the real thing, from the famous haka: " Tenei te tangata puhuruhuru nana mei i tiki mai whakawhiti te ra." Zzxjoanw can't be Maori. In fact, it turns out (Word Ways, November 1976) to have been invented by Rupert Hughes for inclusion in his Music Lovers'Encyclopedia of 1914, where he says that it is pronounced "shaw" and means "1. Drum. 2. Fife. 3. Conclusion."

To which one the only possible concluding response is "Pshaw," followed by a bout of heavy zzzz-ing.

Jeff Aronson clinical pharmacologist, Oxford (jeffrey.aronson@clinpharm.ox.ac.uk) 